\title{
Russia in the Context of Global Trends of Higher Education
}

\author{
Marina Burchakova \\ Peoples' Friendship University of Russian \\ Miklukho-Maklay str., 10/2, Moscow, Russia, 117198 \\ E-mail: burchakovam@bk.ru \\ Yury Moseykin \\ Peoples' Friendship University of Russian \\ Miklukho-Maklay str., 10/2, Moscow, Russia, 117198 \\ E-mail:myn@imeb.ru
}

\author{
Julia Karagod \\ Peoples' Friendship University of Russian \\ Miklukho-Maklay str., 10/2, Moscow, Russia, 117198 \\ E-mail: karagod_yug@pfur.ru \\ Natalia Sakharchuk \\ Peoples' Friendship University of Russian \\ Miklukho-Maklay str., 10/2, Moscow, Russia, 117198 \\ E-mail: sakharchuk_ns@pfur.ru
}

\begin{abstract}
The article provides the main global trends for the development of higher education. They determine the current status and shape the route and prospects of development of a higher education system in the XXI century: globalization, internationalization, the transition to mass higher education, the commercialization, the transition to a "flexible" specialties and competence-based approach, the emergence of new forms of education and the change of education technologies and several others. Identified trends characterize the involvement of Russia in global transition to a post-industrial education. It was found that the Russian system of higher education is more in line with the measure of the international level. However a lag in some indicators was registered.
\end{abstract}

Keywords-higher education; the main trends of development; globalization; internationalization; commercialization; flexible professions; the international market of educational services

\section{INTRODUCTION}

In recent years, the peaceful democratic community has made noticeable efforts to change the general intellectual and spiritual climate of the planet, which complies with new ideological realities. The solution to this problem is united with the level of development of the Institute of Education, which determines the targets of mankind's future. They are manifested in the form of explicit or implicit tendencies. In this regard, the scientific interest of both Russian and foreign researchers is increasing in the crucial area of life as higher education, which has a special significance for the development of the intellectual, cultural and economic potential of the global space.

The aim of this study is to examine the major trends in the development of modern higher education system in foreign countries and in Russia.

Materials and methods. The study of global trends in higher education development was based on the review of the views of domestic and foreign authors on the said issues and the analysis of the experience of leading Russian and foreign universities. We used a systematic approach, methods of comparative analysis, synthesis, induction, deduction, generalization and scientific abstraction. The informational base was formed on the basis of data published in domestic and foreign literature, scientific journals, official use of Internet resources, data of Federal Service of State Statistics, and documents of international organizations to achieve this goal.

The object of the research is the system of higher education in foreign countries and Russia.

In most countries, the conventional concept is considered to be the expansion of higher education; according to this, higher education includes all types of education and training with the term of the training being two years or more, provided that they are part of a study of general scientific (fundamental) disciplines. The main typological division of higher education and universities is respectively held on the grounds of membership to a university or non-university sector of higher education. [6. P. 69] In the university sector of higher education (universities and colleges in Englishspeaking countries and other types of higher education institutions, which formally given university status), the sector provides a comprehensive profile of training and the obligatory presence of a heavy fundamental component. The non-university sector (institutes, high schools, academies) focuses on more specialized and professionally oriented education.

The structure of the organization of higher education in foreign countries is a multi-level and defines a hierarchy of education levels and corresponding diplomas.

The Russian higher education system was formed in the XIX century based on the introduction of the German model of Humboldt University's research, which is based on the ideas of academic freedom and the unity of education and science. The Humboldt University model was so powerful that in the overwhelming majority of cases Western 
European and North American universities correspond to it. Nowadays, this model largely determines the face of the global system of higher education.

The German model was the most suitable for implementation in the reforming period in the Soviet state. However The Gumboldovskaya model was carried out in the Soviet Union with the distortion of the basic principle of the classical German university - the principle of academic autonomy, whose roots go deep into the history of the medieval university. The organization of educational process, however, was copied completely. This enabled the Soviet Union in the short term to create a competitive system of higher education.

During the period of industrialization occurred the most large-scale transformations in the Soviet higher education system, due to the need of the mass training of engineers. The number of higher schools in the Soviet Union increased from 150 in 1917 to 516 in 1950. Almost all universities were enacted with a technical school function. In the 20-30s of the XX century the most of humanitarian specialties was removed from the university and is concentrated in pedagogical institutes and specialized universities. At the same time scientific and technological working have been removed from the higher education system and transferred to specialized academic institutions. Soviet universities no longer belonged to the Gumboldovskaya model and became essentially technical schools.

By the early 90s of the XX century, the Russian system of higher education began to lose its global competitiveness. Since the mid-90s higher educational institutions have begun to actively carry out the conversion, trying to adapt with new realities and to grasp new trends in the global education system.

In modern Russian higher education actively developed and integrated into the European Bologna Process. The system of higher school is a multi-level, which defines the following levels: Specialty - 5-6 years of study; Bachelor - 4 years of study; Masters - 2-year of study (training possible after receiving the bachelor's degree) and postgraduate education [20. PP. 5-23].

Bachelor's program is more practice-oriented, master's program allows students acquire the competencies needed for future research or teaching activities.

\section{MODERN TENDENCIES OF HIGHER EdUCATION DEVELOPMENT}

Today we can identify a number of important trends and features of the system of higher education development in the world, which are largely inherent in Russian higher education.

\section{A. Involvement of Higher Education in the Processes of Globalization}

At the turn of XX and XXI centuries, the process of globalization had accelerated noticeably under the influence of revolutionary changes in technology and science. The appearance of high-speed means of communication and the progress in the development of electronic means of communication to a large extent contributed to the blurring of frontiers and the bringing of people closer together. Realizing the nuclear threat, the danger of international terrorism caused the need for joint solutions to these problems, as well as the creation of the collective security systems and joint intervention in the natural processes of the development and application of the scientific and technological revolution. Under the influence of these reasons brought to life the idea of global governance global processes.

The system of education, and especially the higher education system is the most widespread and the most susceptible to the influence of external factors spheres of socio-economic and cultural life in all countries.

The international organization, UNESCO, globalizes modern educational space, bringing it to the level of any new pressing challenges facing humanity. Its activities in this area are aimed at solving the problems of educating people in the spirit of peace, democracy, progress and universal humanism, respect for human rights, cross-cultural differences, values and traditions of other peoples, respect for the environment. Currently, it performs the process of UNESCO coordinator of the global educational space and develops for all countries in international legal instruments, both global and regional. The report on the state of education of the world, published by UNESCO in 2000, emphasized that "the need to improve the education system became more urgent as there is no huge changes brought about by globalization and the development of information and communications technologies taking place in the world" [7. P. 192]. Globalization in the economic field and the rapid development of information technologies form the global knowledge economy.

According to globalization in the context of education written by many Russian and foreign authors, all higher education institutions, one way or another, are involved in the processes of globalization, and that globalization itself - a new phenomenon distinct from internationalization - is inseparable from the new forms of social life and the new paradigms of knowledge production.

Researchers identify the main challenges and threats of globalization for higher education [1]:

1) the existence of strong competitors in the market (for example, a small local school, even occupying the leading position in the region and the university with a worldwide reputation);

2) the difficulty or even impossibility of attracting foreign students;

3) the growth in popularity of distance learning.

4) one of the most powerful global trends of the modern world of higher education is the transition from an industrial sample of high school to high school postindustrial era. 


\section{B. Internationalization of Education}

According to foreign researchers, internationalization is based on a world order in which the dominant role belongs to nation states with clear political boundaries, through which can be a traditional activity on the internationalization of education; that is, the movement of students, exchange of personnel, university cooperation, joint research work. At all times, universities are international [14. PP. 3-8].

The term "European education" is widely used in the European Union and the Bologna process. It has been suggested that the "Europeanization - is a special case of internationalization, the internationalization within the geopolitical territory of Europe or internationalization, enhanced by the European interests» [9].

To characterize the complex and multidimensional process of internationalization of education is also often used the concept of "international education", "multicultural education", "export of educational services", "integration of educational systems", "Europeanization of education." They are basic, and the distinction between them is one of the most important methodological problems [2. P. 49].

In the mid-90s of XX century a new wording appeared in the Western countries - "internationalization at the institutional level in terms of the desired results." An English explorer named George Knight defines internationalization at this level as the introduction of an international dimension in the educational institution functions such as teaching, research, the provision of services [10. P. 94].

In fact, the overwhelming majority of researchers' internationalization recognized the international component of education. It is aimed at an international organization of the educational process and the convergence of national systems of education - finding common ground in their mutual enrichment and taking into account the specificities of national education systems. Accepted entities provide three main forms of internationalization: student mobility, mobility programs and mobility of higher education institutions, which are reflected in collaborative research, recognition of diplomas and degrees, the general standard of education, etc. Today, the leader of the world's export of education is the United States. They are leading in the number of enrolled foreign students and cover about $30 \%$ of the market of educational services. In second place is the United Kingdom, followed by Germany, France, Australia, Spain, Canada and Russia. In the 2014-2015 school year in Russia 84.4 thousand people from the CIS countries were trained and 221.4 thousand people from foreign countries. A quarter-century ago, Russia shared with the United States the first or second place in the world in the number of foreign students, but now it lags behind [17].

Announced sanctions against Russia negatively impacted the development of education in Russia, since the implementation of the priority research projects, exchange of students, and development of universities is based on the absorption of advanced foreign experience and on promoting the development of international cooperation.

\section{The Transition to Mass Higher Education}

In developed countries, the tendency in the last 70-80 years of the XX Century has been to increase the number of people receiving higher education. For example, in Europe the average number of students from 1960 to 1980, increased by three and a half times, and in countries such as Finland, Sweden and Italy - 6 times. The number of students in Spain and Norway increased 10 times. In developed countries, the number of applicants to higher education school graduates was in 1995 - 60\%, in North America - 84\%, in developing countries, the number covered by the higher education has increased in recent years by 11 times. This trend slowed down somewhat until the beginning of XXI century.

According to a study conducted by the "Center for Strategic Research - North-West" in 2005 in Russia the number of people receiving higher education since the early 90s increased almost two and a half times: from 190 to 448 students per each 10 thousand people of the population.. In 2015 , the number of students amounted to more than 5 million people. The number of universities has also increased significantly. In fact, Russia has become a country of universal higher education. In the Soviet Era, there were 5 times fewer universities.

A specific feature of the Russian transition to mass higher education was the coincidence of this process with the beginning of a prolonged demographic decline and quite a difficult economic situation in the 90s. However, in some regions of the Russian Federation the number of students in 1995 increased three or four times, despite the fact that these regions had lost up to $20 \%$ of the population [12. PP. 108119]. In some years the number of applicants exceeds the number of people graduating from school this year.

In the developed countries of Europe and America the transition to mass higher education took place against the backdrop of economic recovery and the effects of the postwar baby boom.

The reasons for the transition to mass education in higher education are the same for all countries, including Russia. First of all, it is a sharp increase in the number of jobs requiring applicants to a higher, complex and continuous training, as compared with the fact that offers primary and secondary vocational education. Higher education in an unstable situation in the labor market increases the competitiveness and adaptability of job seekers. In addition, at the end of the XX century has changed the social function of higher education, which stands today as the union of three kinds of socially important social institutions of science, education and culture [21. PP. 91-97].

Higher education has become the minimum necessity for the development of a professional and social career. In Western countries, the issue of mass higher education has become an important element of democratization providing access to education for the entire population, regardless of social background and financial situation, the succession of stages and levels of education. 
Experts predict that the number of students will double in 10 years, largely as a result of increasing the number of tertiary education in Asia and Europe [19. P. 3].

\section{Commercialization of Higher Education and \\ Transformation of Universities into Businesses}

During the last thirty years all over the world the proportion of paid higher education increases. Commercialization is embodied in the emergence of a qualitatively new model of higher education called the pragmatic model. The pragmatic model focuses on service, commercial, and entrepreneurial function. The reorientation of higher education institutions is not a choice of values, but rather a necessary measure undertaken in the face of declining funding from the state.

During the transition to mass education in the developed countries, the main investor investing in training was the state, but more and more often individuals began to act as investors and facilitate the growth of paid education and the expansion of the segment of private universities. In some countries, paid education grew, but at the same time revised the ideology of state support for education. Government funding of universities has begun to move to the financing of citizens seeking higher education. In practice, including and in Russia, have entered normative per capita financing, loans and so on. Today, private education predominates in the system of higher education, not only in Anglo-Saxon countries, where education has traditionally financed mainly from non-governmental sources, but also in Japan, South Korea, Taiwan, the Philippines, Chile, Armenia. By the early '90s is not less than half of Latin American students enrolled at private universities. In the US, more than 3,000 higher education institutions of different types, half are private. In Japan, 425 of the 600 universities are private.

The formation of the education market has changed and the very system of higher education. Universities have become the subjects of market relations: they began to restructure its assets, and the beginning of the $80 \mathrm{~s}$ the research function of universities has acquired the features of commodities - scientific and engineering knowledge would be translated into commercial products, licenses and patents, which can be bought and sold on the market. The universities were turned into the place of production is not as much knowledge as innovative technologies and new staff positions in the labor market.

Currently, the relationship between teacher and student become more market-oriented: the teacher sells its services the student buys or orders new ones, if it does not meet with the proposed services. Students can not only buy their own educational services on the market, but also they can configure the set of these services so that facilitates the capitalization of the value of their labor. Disciplines reoriented to the immediate needs of the market, with the result that there is a "reduction" fundamental importance of the system.
Fundamental science give way to the so-called "useful knowledge", i.e. knowledge applied primarily numerous special courses.

Also the attitude of students and their parents has changed concerning the university education. It is becoming increasingly consumer. The basic principle in the selection of the institution to the future student and his parents become "price-quality" as well as the positioning of the university and the university's rankings in advertising.

The personal strategy of continuing education in the postindustrial age differs significantly from corporate and government strategies for periodic training and staff development, dominated the industrial era. In a society gradually formed human position, chooses its own capitalization strategy.

In Russia, historically, since imperial times, the education system was mainly free. The first paid places in public universities have appeared in post-Soviet Russia in 1992. The demand for paid services to higher education began to take shape from this time, i.e. before the opening of the first private universities that appeared in Russia in 1995. In 1995, the number of business students in Russian universities was $10 \%$ of the total, but by 2000 the number of first-year students enrolled in low places and the number of students who have paid their education, almost equal.

Institutional reforms are widely affected region of the Russian higher education system, which is reflected in the change of its quantitative and qualitative characteristics. The country is changing the ratio of public and private universities, the number of students. Clearly there has been a trend of restructuring universities by optimizing and reducing the staff of higher education institutions and actively developing student services.

Now in Russia 950 accredited higher education institutions operate, including 548 state and non-state 402: the number of branches of several thousand educational institutions. The scope of paid education currently occupies a large enough segment of the Russian education system. In 2015 , it accounted for $42 \%$ of all universities in the country "Table I". 
TABLE I. EDUCATIONAL INSTITUTIONS OF HIGHER EDUCATION IN RUSSIA THE PERIOD OF 2000-2015 [4]

\begin{tabular}{|l|l|l|l|l|}
\hline \multicolumn{1}{|c|}{ Years } & $\begin{array}{c}\text { The number of state and } \\
\text { municipal educational institutions } \\
\text { of higher education }\end{array}$ & $\begin{array}{c}\text { Enrolled students - } \\
\text { total, thousand } \\
\text { people }\end{array}$ & $\begin{array}{c}\text { Private educational } \\
\text { institutions of higher } \\
\text { education }\end{array}$ & $\begin{array}{c}\text { Enrolled students - } \\
\text { total, thousand } \\
\text { people }\end{array}$ \\
\hline $2000 / 2001$ & 607 & 4270,8 & 358 & 470,6 \\
\hline $2005 / 2006$ & 655 & 5985,3 & 413 & 1079,3 \\
\hline $2006 / 2007$ & 660 & 6133,1 & 430 & 1176,8 \\
\hline $2007 / 2008$ & 658 & 6208,4 & 450 & 1252,9 \\
\hline $2008 / 2009$ & 660 & 6214,8 & 474 & 1298,3 \\
\hline $2009 / 2010$ & 662 & 6135,6 & 452 & 1283,3 \\
\hline $2010 / 2011$ & 653 & 5848,7 & 462 & 1201,1 \\
\hline $2011 / 2012$ & 634 & 5453,9 & 446 & 1036,1 \\
\hline $2012 / 2013$ & 609 & 5143,8 & 437 & 930,1 \\
\hline $2013 / 2014$ & 578 & 4762,0 & 391 & 884,7 \\
\hline $2014 / 2015$ & 548 & 4405,5 & 402 & 803,5 \\
\hline
\end{tabular}

The problem of opening a plurality of non-state universities in Russia lies in the fact that some of them do not meet modern requirements submitted to the Higher School institutions; i.e. they are not provided with any material resources or teaching staff. In this regard, the concept of the Federal target program of educational development for 2016-2020 years provides for the reduction in the number of high schools by 40 percent, and their branches -80 percent [16].

In the last decade throughout the world and in Russia in particular, there has been a significant increase in fees for education, both in private and in public universities.

For example, in the US, the fee for a year of study in an inexpensive public state university is $\$ 18,000$, at Stanford and Harvard, it comes now to $\$ 44,000$ per year [13].

The maximum price for the training in the best universities of Russia today ranges from \$14 thousand to \$24 thousand [15]. Features of the same quality education for most of the Russian population decreased; even in the case of training at the expense of the state budget, the cost of living in metropolitan areas, where most of the elite universities, proves to be an insurmountable financial barrier for a large part of provincial students.

\section{E. Go to the "Flexible" Function and the Competency Approach}

In the period following the Second World War, in all developed countries the number of new jobs clearly increased. In the United States, "National Register of scientific and technical staff" of 20 years after the war has increased from 54 to 900 specialties. The employers' requirements changed to applicants for jobs. The labor market began to demand "flexible" specialists able to perform work affecting different branches of knowledge and skills to be adapted to the rapid change of work. The list of new specialties grew rapidly, some of them stands out from the old, often occurs at the intersection of traditional disciplines.

The education system reacted to the changing conditions of the labor market and employers to increase the number of specialties, the growth of multidisciplinary forms of education and the transition to a competency-based learning. There was thus implemented migrate instruction form in which the focus was shifted from the result of the learning process. The acquisition of "soft" disciplines should contribute to a "flexible" learning process.

To synchronize the dynamics of education and the rate of change, the labor market in the US has widely introduced modular training programs; the number of cases has increased in the educational process in order to deepen specialization in practical matters. In American universities the continuity of educational programs at different levels of permeability guarantee students the opportunity to continue their education.

The emergence of flexible specialties requires radical changes in the system of assessing the quality of educational programs. In place of the results of the final tests come indicators of successful work of graduates, for example, the size of their remuneration after graduation.

In the USSR, training for the national economy was clearly dominated by a technocratic approach. Engineers were produced at a rate three times more than that of the United States, while economists were produced at a rate three times less. Economists in Soviet universities were taught mainly in industrial technical colleges.

In the 90s training structure has changed in Russian universities. It began replenishing humanitarian training and the number of students majoring in "Economics and Management" has increased four-fold, increase in the number of students in philology, history, psychology, sociology, PR. The number of implemented educational programs of Russian universities, from 2000 to 2012 increased from 20 thousand to 36 thousand due to the opening of new special economic, legal and humanities. However, the quantitative growth of the Russian experts in the field of management and services was not accompanied by the growth of the quality of their training. Getting a diploma is no longer guarantee the success of the employment and career development. The reasons for this were lagging behind in the field of university management reforms, the lack of well-known domestic humanitarian schools, the dominance of the theoretical component of the training of students, bureaucratic obstacles.

To overcome this situation, eliminate distrust of higher education system and give greater adaptability of the whole process of learning to develop educational standards today, 
employers are attracted to Russia. The process of preparing a Russian university graduates was reoriented to the new concept of work culture and responsible for the results, the formation of the ability to quickly develop professional skills.

\section{F. The Emergence of New Forms of Education}

Increased competition in the international market of educational services, going beyond the traditional conceptual, institutional, and geographic boundaries and the second wave of institutional diversification, led to the emergence of new forms of education.

Among the new actors of the global educational space today are virtual license (franchise) and corporate universities; libraries, museums and intermediary organizations by the media, professional associations; brokers in the field of education, companies with a large staff requirements. They were closely followed by software vendors, publishers, entertainment companies, who are also seeking to capitalize on the potential of a new international market for higher education services.

The strong position in the market of developed countries, educational services already takes distance education. Open University of the UK for 25 years of its existence has become a leader and become a pan-European university without borders.

In Russia, the formation of this market space is relatively recent, but the corporate universities, distance education, community business education and training system, are helping to accelerate the preparation of students for work in the conditions of an overactive labor market and have an impact on the education market.

Special features of this new trend in Russia can be attributed to the fact that new market participants often come in the segment of management education. The cost of education is much higher than in traditional universities, with some new subjects and services have not yet been institutionalized (or through legal mechanisms, either through a system of social relations); often the new services in the field of business education, training offer old participants of the market - the traditional Russian universities.

\section{G. Change of Educational Technology}

Since the $70 \mathrm{~s}$ the proportion of schools, practicing traditional class-lesson course of study designed by Jan Amos Comenius, declined steadily. Today, the "contact forms of learning" in all countries account for only $15-20 \%$ of the total training volume. Education based on the principle of "learning all around," appeared in a state of crisis. University education is not just not cope with the ever increasing flow of information, it has lost its ontological base in the form of a universal philosophy, allowing to harmonize specialized science [12. PP. 108-119]. Modern science is constantly faced with the fact that it was no longer able to anticipate all risks incurred based on its work. All this led to the need to shift the emphasis from the passive transfer of knowledge in the sphere of the practical action zone. In the foreign universities, for a long time, there was a shift from the narrative ways of learning to the activity.

In the US, one of the main institutions of higher educational teaching methods is the case-study method, which involves problem solving and requires no memorizing, just thinking and finding solutions. Many foreign universities have translated a large part of their courses in electronic form and made it publicly available.

The basic technological training in Russian universities is still the lecture and seminar, and the payment of the teaching staff working is hourly. At the same time, the payment of teachers abroad, acting as repeaters of information, becomes lower.

\section{CONCLUSION}

Dedicated leading global trends in the development of high school determines the current state and forms the direction and prospects of the development of a higher education system in the XXI century.

The analysis of educational globalization suggests that globalization processes will be further developed. In the transition to a knowledge society, globalization makes higher education more and more important requirements as knowledge centers. The priorities of the new educational paradigm becomes a focus on the interests of the individual, in this regard, democratization, humanization and humanization of higher education become its major trends. Emphasize integration educational processes.

Under the influence of globalization in the XXI century greatly enhanced the trend of internationalization of education. It will continue to grow its share of the international component. The internationalization of higher education in foreign countries and Russia have become the object of a targeted state policy.

Economic development and population growth will continue to drive demand in the world for higher education, but not all countries will be able to meet this demand due to a lack of sufficient resources. The possibility of obtaining higher education will remain mainly for members of the upper and middle classes. The demand for higher education will increase not only in quantity, but will also become more diversified.

Russia's share in the world market of educational services in the coming years will continue to decline, mainly due to the lack of a competitive product, the fact that it is not always in accordance with international standards, and the poor educational infrastructure.

Because of the growing demand for higher education, the existing budget problems, and the lack of resources faced by many countries in the world, new information and communication technologies create the preconditions for the expansion of private sector education. In Russia, the commercialization of higher education is fast, and especially today, there is a question about the quality of the proposed paid educational services. Modern Russia has a significant number of private universities that have taken the path of 
development of higher education in the United States and Japan, where there are highly developed private segments.

Identified trends characterize the involvement of Russia in a global transition to a post-industrial education. The Russian system of higher education is more in line with international criteria. In addition, there is a lag in the number of indicators from other developed countries: on the development of research in higher education institutions, the transition to a "flexible" function, the development of new forms of education, the introduction of new educational technologies, the market position in the world and the internationalization of higher education. And although the restructuring of Russian education systems began only a quarter of a century ago, it is yet too slow.

\section{REFERENCES}

[1] A. Grudzinski, Design-oriented university. Nizhny Novgorod: Nizhny Novgorod State University, 2004;

[2] A. Pirogov, G. Krasnova and V. Filippov, Trends in the development of higher education reforms in the CIS. Moscow: People's Friendship University, 2008, p. 49;

[3] D. Alexandrov, Actual problems of globalization. Moscow, 2000;

[4] Educational institutions of higher education. Rosstat. (Electronic Publication:

http://www.gks.ru/free_doc/new_site/population/obraz/vp-obr1.htm);

[5] Focus on the Structure of Higher Education in Europe 2006-2007. National Trends in the Bologna Process // EURY-DICE. The information network on education in Europe, 2007;

[6] G. Tkach, V. Filippov and V. Chistokhvalov, Trends in the development and education reform in the world. Moscow: People's Friendship University, 2008, p. 69 (Electronic Publication: http://web-local.rudn.ru/web-local/uem/iop_pdf/247-Tkach.pdf);

[7] Global Education Digest 2000. Moscow: UNESCO, 2000, p. 192;

[8] Globalization: a new paradigm for higher education policy. // Higher education in Europe.Volume XXVI, number 1, 2001;

[9] H. Kelen, Concept of further development of internationalization in practice: decade, the evolution. // The higher education in Europe. Volume XXV, number 1, 2000;

[10] J. Knight. Measurement of internationalization features. London, 1995, p. 94;

[11] Joseph Stiglitz, Globalization: disturbing trends. Moscow: Thought, 2003;

[12] M. Galushkina, V. Knyaginin, Mass, flexible and international. // Expert, number 43, November 2005, pp. 108-119;

[13] Official site of the Harvard University. (Electronic Publication: https://www.unipage.net/ru/harvard_university);

[14] P. Scott, Globalization and University // Moscow: Alma Mater, 2000, №4, pp. 3-8.

[15] Rating universities: most expensive Russian universities. (Electronic Publication: http://moeobrazovanie.ru/reiting_samye_dorogie_vuzy_rossii.html)

[16] Russian Federation Government Resolution of May 23, 2015 number $497 \ll$ On the Federal target program of education development for 2016 - 2020». (Electronic Publication: http://base.garant.ru/71044750);

[17] Russian Statistical Yearbook, 2015. (Electronic Publication: http://www.gks.ru/free_doc/doc_2015/year/year15.rar);

[18] V. Chistokhvalov, Features of modernization of the Russian and European higher education in 1991-2005: historical and comparative analysis. Moscow: People's Friendship University, 2008, p. 331;

[19] V. Galichin, International market of educational services: the main features and trends. Moscow: Delo, Russian Academy of National
Economy and Public Administration under the President of the Russian Federation, 2015, p. 3;

[20] Y. Moseykin, La influencia del proceso de Bolonia en las reformas de la educacion superior de America Latina y Rusia. Yearbook of Research and Education Center for Latin American Studies, 2014. Moscow: Peoples' Friendship University of Russia, pp. 5-23;

[21] Y. Moseykin, Modern trends in the world market of educational services // Business education, number 2 (25), 2008, pp. 91-97. 